\title{
The exercise of sexuality among the elderly and associated factors
}

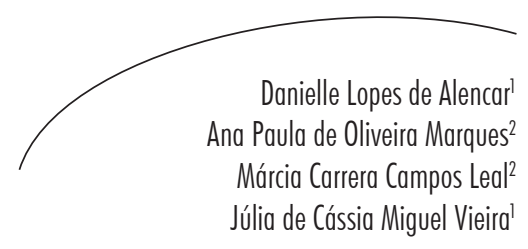

Abstract

Objective: To analyze factors that interfere with the exercise of sexuality among the elderly. Methods: A cross-sectional study of 235 elderly persons enrolled at the Open University of the Third Age of the Federal University of Pernambuco was carried out. The dependent variable was the exercise of sexuality, which was investigated in terms of perception of sexuality, thinking about sex, what the elderly person does when he or she has the desire for sex, sexual activity and auto-eroticism. The independent variables were sociodemographic data, health status and self-perception of body image. Statistical analysis involved bivariate correlation by the Kendall and Spearman coefficients. All variables with $p \leq 0.20$ in bivariate analysis were included in the generalized linear regression, with $p=0.05$ considered for the rejection of the null hypothesis. Result: The conception of sexuality was most closely related to genitality $(67.2 \%), 51.5 \%$ of the sample reported Keywords: Aging. Sexuality. thinking about sex, while $71.1 \%$ of the elderly persons said they were indifferent to sexual desire; $32.3 \%$ claimed to be sexually active; and 23\% auto-eroticized. The variables age, years of education, religion, physical exercise and dissatisfaction with body image were significant in bivariate correlation analysis. The desire for sex and sexual activity were less likely to be present among elderly persons who performed exercise. Conclusion: The sexuality of the elderly is based on several factors that may interfere with their experience and should be considered in educational strategies employed by health professionals who promote actions for the sexual health of the elderly.

\footnotetext{
${ }^{1}$ Universidade Federal de Pernambuco. Departamento de Enfermagem. Recife, Pernambuco, Brasil.

${ }^{2}$ Universidade Federal de Pernambuco, Departamento de Medicina Social. Recife, Pernambuco, Brasil.

Correspondence

Danielle Lopes de Alencar

E-mail: enfaalencar@gmail.com
} 


\section{INTRODUCTION}

Old age is often marked by negative stereotypes related to decline and the loss of function, meaning it is important for health professionals to visualize all the features of elderly persons, including their sexuality. Such a term goes beyond the sexual act and expresses itself in a number of ways. Caresses and touching play a key role in the exercise of sexuality.

Sexuality among the elderly is a continuation of a process begun in childhood. It is an inherent part of the individual, present in every act of his or her life. Each person determines, in a particular and individual manner, how sexuality is manifested, communicated, felt and expressed. ${ }^{2}$

Based on the perspective that sexuality is a continuation of the existence of the individual and that even if the practice of sex is reduced or the elderly individuals themselves internalize negative stereotypes about their sexuality, the subject in question should be addressed by health services, using health education as a means of constructing new concepts about the sexuality of the elderly. The objective of the present study was therefore to analyze factors that interfere in the exercise of sexuality among elderly persons.

\section{METHOD}

An analytical, cross-sectional study with a quantitative approach was carried out at the Universidade Aberta à Terceira Idade (University of the Third Age) (UnATI) of the Universidade Federal de Pernambuco (Pernambuco Federal University) (UFPE) and is part of a dissertation work.-

A sample error of $0.05 \%$, prevalence of sexually active elderly persons of $0.5 \%$ (based on data taken from a pilot study), and a level of confidence of $95 \%$ were used to calculate the sample. The population was elderly persons ( $\mathrm{n}=605)$ enrolled on courses offered by UnATI in the $1^{\text {st }}$ semester of 2012 , resulting in a sample of 224 women and 11 men. There was a significant predominance of women, who make up the majority of the students of the courses offered, resulting in a disparity in the sample, of which only $4.7 \%$ were men. For this reason, the sample design was stratified by gender, in order to qualify the evaluation of the results.

Those eligible for the study were all elderly persons enrolled on the courses offered during the investigation period, excluding those with impaired communication and/or cognition which would interfere with data collection during the realization of the interviews.

The exercise of sexuality was investigated using the following aspects: conception of sexuality: an open question, with answers subsequently grouped into six categories: sexuality is not just sex $(\mathrm{n}=10)$; it involves feelings and touching between a couple $(\mathrm{n}=7)$; it is part of life, promoting happiness for the elderly person/couple ( $\mathrm{n}=31$ ); sexuality is having sex ( $\mathrm{n}=138)$; pleasure/desire in the sexual act $(\mathrm{n}=10)$; bodily needs $(\mathrm{n}=10)$. For statistical analysis the categories found were organized into two blocks: perception of sexuality from a holistic perception and sexuality based on genitality.

In the holistic vision, sexuality is understood through the expression and experience of being a woman and being a man, not simply through the sexual act, and is characterized by love, affection, and giving, with the valuing of feelings such as companionship, partnership, hugs, caresses and kisses. Sexuality is part of the life of a human being, and is present in every phase of growth, from birth until death. ${ }^{3-7}$

In a vision based on genitality, sexuality is related to sex and reduced to the genitals and coitus. When the meaning of sexuality relates only to having sex, it implies that when the elderly stop having sex, they become asexual. ${ }^{6,8,9}$ 
The independent variables were represented by socio-demographic data (gender, age, marital status, education and religion), health status (selfperceived health), morbidities, medical diagnosis, physical exercise and self-perceived body image, which was evaluated using the Stunkard, Sorensen and Sunkard questionnaire. ${ }^{10}$

Data was collected between May and June 2012, when the elderly persons were recruited in UnATI by a researcher who informed them about the study and its objectives, based on their interest. The interview took place in an individual room, allowing privacy between the researcher and the interviewee. Four previously trained graduate students took part in the data collection. To adjust for possible inconsistencies in the data collection protocol, a pilot study was carried out, and three questions were reformulated. Interviews were chosen as a data collection technique, with the application of a semi-structured instrument.

At the end of data collection, a database was constructed using the EpiInfo 3.5.2 program, with data entered using the double entry system. This database was then transferred to the $R$ program version 2.15.0 for statistical analysis. The Spearman and Kendall coefficients were employed in bivariate analysis.

The generalized linear regression model included all variables that achieved $p \leq 0.20$ in bivariate analysis. The Student's t-test was applied to each of the parameters to verify significance, adopting a $\mathrm{p} \leq 0.05$ value for the rejection of the null hypothesis of the study.

The present study was carried out in accordance with the ethical precepts of Resolution no 196/96 and was approved by the UFPE Ethics Committee under CAAE no 01651112.5.0000.5208. The participants were fully informed about the aims of the study as well as its risks and benefits. At the end of the interviews, the elderly persons signed a Free and Informed Consent Form and later received educational material regarding sexuality.

\section{RESULTS}

Of the 235 elderly persons interviewed, $95.3 \%$ were female. A total of $54 \%$ of the sample was aged between 60 and 69 years. In terms of marital status, $36.6 \%$ were single, while $34 \%$ were married. A total of $64.7 \%$ had nine years of schooling or more, while $3.8 \%$, all of whom were women, had no education; $97 \%$ said they were religious, of whom $66.4 \%$ were catholic, $16 \%$ were evangelical protestants, $13.6 \%$ were spiritualists and $0.9 \%$ had other religious beliefs.

In terms of the self-perception of health, $42.1 \%$ described their health as good and $41.3 \%$ said it was fair. Systemic arterial hypertension (61.3\%) and diabetes $(14.9 \%)$ were the most commonly cited morbidities. A total of $64.7 \%$ performed physical exercise, defined as a minimum of three times a week with a minimum duration of 30 minutes for each session, with walking the most frequently cited activity. Regarding body image, $53.6 \%$ considered themselves dissatisfied due to body fat and $6.8 \%$ due to thinness.

Genitality $(67.2 \%)$ was significant as a conception of sexuality. Of the total sample, $51.5 \%$ described thinking spontaneously about sex, while in terms of sexual desire, $71.1 \%$ reported indifference, $20 \%$ sought sexual relations with their partner, $6.8 \%$ auto-eroticized and $2.1 \% \mathrm{did}$ not respond. A total of $32.3 \%$ of those interviewed were sexually active while auto-eroticization was described by $23 \%$. 
Table 1. Characterization of elderly persons interviewed based on sociodemographic variables, health conditions and self-image scale. Recife, Pernambuco, 2012.

\begin{tabular}{|c|c|c|c|}
\hline Variable & n $(\%)$ & Women $(\%)$ & $\operatorname{Men}(\%)$ \\
\hline Sample & $235(100)$ & 224(95.31) & $11(4.69)$ \\
\hline \multicolumn{4}{|l|}{ Age Range (years) } \\
\hline 60 to 69 & $127(54.0)$ & $119(53.1)$ & $6(54.5)$ \\
\hline 70 to 79 & $87(37.0)$ & $83(37.1)$ & $4(36.4)$ \\
\hline 80 or more & $21(9.0)$ & $20(8.9)$ & $1(9.1)$ \\
\hline \multicolumn{4}{|l|}{ Marital Status } \\
\hline Married & $80(34.0)$ & $73(32.6)$ & $7(63.6)$ \\
\hline Widowed & $29(12.3)$ & $29(12.9)$ & $0(0.0)$ \\
\hline Single & $86(36.6)$ & $86(38.4)$ & $0(0.0)$ \\
\hline Separated & $40(17.0)$ & $36(16.1)$ & $4(36.4)$ \\
\hline \multicolumn{4}{|l|}{ Schooling (years) } \\
\hline None & $9(3.8)$ & $9(4.0)$ & $0(0.0)$ \\
\hline 1 to 4 & $19(8.1)$ & $18(8.0)$ & $1(9.1)$ \\
\hline 5 to 8 & $55(23.4)$ & $52(23.2)$ & $327.3)$ \\
\hline$\geq 9$ years & $152(64.7)$ & $145(64.7)$ & $7(63.6)$ \\
\hline \multicolumn{4}{|l|}{ Religion } \\
\hline Yes & $228(97.0)$ & $220(98.2)$ & $8(72.7)$ \\
\hline No & $7(3.0)$ & $4(1.8)$ & $3(27.3)$ \\
\hline \multicolumn{4}{|l|}{ Self-perception of health } \\
\hline Excellent & $27(11.5)$ & 26(11.6) & $1(9.1)$ \\
\hline Good & $99(42.1)$ & $92(41.1)$ & $7(63.6)$ \\
\hline Fair & $97(41.3)$ & $94(42.0)$ & $3(27.3)$ \\
\hline Poor & $12(5.1)$ & $12(5.4)$ & $0(0.0)$ \\
\hline \multicolumn{4}{|l|}{ Performs Physical Exercise } \\
\hline Yes & $152(64.7)$ & $143(63.8)$ & $9(81.8)$ \\
\hline No & $83(35.3)$ & $81(36.2)$ & $2(18.2)$ \\
\hline \multicolumn{4}{|l|}{ Satisfaction with body image } \\
\hline Satisfied & $97(41.3)$ & $91(40.6)$ & $6(54.5)$ \\
\hline Dissatisfied due to overweight & $122(51.9)$ & $120(53.6)$ & $2(18.2)$ \\
\hline Dissatisfied due to thinness & $16(6.8)$ & $13(5.8)$ & $3(27.3)$ \\
\hline
\end{tabular}


Table 2. Exercise of sexuality as described by elderly persons, with regard to conception of sexuality, thinking about sex, what to do when experiencing sexual desire, sexual practices and auto-eroticization. Recife, Pernambuco, 2012.

\begin{tabular}{lccc}
\hline Variable & $\mathrm{n}(\%)$ & Women $(\%)$ & Men(\%) \\
\hline Sample & $235(100)$ & $224(95.31)$ & $11(4.69)$ \\
Conception of sexuality: & & & \\
$\quad$ Holistic & $48(20.4)$ & $45(20.1)$ & $3(27.3)$ \\
$\quad$ Genitility & $158(67.2)$ & $150(67.0)$ & $8(72.7)$ \\
Did not respond & $29(12.3)$ & $29(12.9)$ & $0(0.0)$ \\
Think about sex & & & \\
Yes & $121(51.5)$ & $114(50.9)$ & $7(63.6)$ \\
No & $114(48.5)$ & $110(49.1)$ & $4(36.4)$ \\
What do you do when you experience desire & & & \\
Indifferent & $167(71.1)$ & $158(70.5)$ & $9(81.8)$ \\
Seek sexual relations & $47(20.0)$ & $45(20.1)$ & $2(18.2)$ \\
Auto-eroticization & $16(6.8)$ & $16(7.1)$ & $0(0.0)$ \\
Did not respond & $5(2.1)$ & $5(2.2)$ & $0(0.0)$ \\
Practices sex & & & $3(27.3)$ \\
Yes & $76(32.3)$ & $73(32.6)$ & $8(72.7)$ \\
No & $159(67.7)$ & $151(68.4)$ & $4(36.4)$ \\
Auto-eroticization & & $54(24.1)$ & $7(63.6)$ \\
Yes & $54(23.0)$ & $170(75.9)$ & \\
No & $177(75.3)$ & & \\
\hline
\end{tabular}

The variables that crossed with the variables of exercise of sexuality and which were significant in terms of the Spearman and Kendall correlations were analyzed using bivariate correlation (Table 3). They were later analyzed in the multiple regression model, in which only variables with $p \leq 0.05$ were considered.

In generalized linear regression, the logit link function was used for all significant bivariate analyzes of the parameters of the exercise of sexuality with the independent variables. There was a statistically significant link between conception of sexuality and years of study ( $p=0.012$ ), with elderly persons with nine or more years of study being more likely $(85.08 \%)$ to have a holistic conception of sexuality.

In terms of the analysis of thinking about sex and sexual activity, there was a significant relationship with the performance of physical exercise. The parameter calculated indicates that the probability of elderly persons thinking about sex and engaging in sexual activity is lower (55.11\% and $63.98 \%$, respectively) among those who performed exercise. No statistical significance was observed with respect to autoeroticization. 
Table 3. Binary correlation of exercise of sexuality variable with independent variables. Recife, Pernambuco, 2012.

\begin{tabular}{lll}
\hline Independent variables & Dependent variable & Correlation \\
\hline Age Range & Conception of sexuality & $\mathrm{p}<0.05 \mathrm{~b}$ \\
Years of Schooling & Conception of sexuality & $\mathrm{p}<0.02 \mathrm{a}$ \\
- & Think about sex & $\mathrm{p}<0.09 \mathrm{~b}$ \\
Religion & Practices sex & $\mathrm{p}<0.15 \mathrm{~b}$ \\
Perform Physical Exercise & Think about sex & $\mathrm{p}<0.04 \mathrm{~b}$ \\
- & Practices sex & $\mathrm{p}<0.03 \mathrm{~b}$ \\
Disatisfaction with Body Image & & \\
- & Think about sex & $\mathrm{p}<0.10 \mathrm{~b}$ \\
\hline
\end{tabular}

a: Kendall correlation; b: Spearman correlation

Table 4. Generalized linear regression of exercise of sexuality variable with significant variables from binary correlation. Recife, Pernambuco, 2012.

\begin{tabular}{llcc}
\hline Independent variables & Dependent variable & Parameter & $p$ value \\
\hline Years of Schooling & Conception of sexuality & 0.8545 & 0.012 \\
Perform Physical Exercise & Think about sex & -0.5511 & 0.048 \\
& Practices sex & -0.6398 & 0.027 \\
\hline
\end{tabular}

\section{DISCUSSION}

Sexuality in old age remains permeated by taboos that describe it as an embarrassing subject to talk about, which remains little discussed in health services and in social contexts. While the elderly people interviewed were willing to take part, some refused to participate as they considered themselves ineligible due to no longer being sexually active. Everyone, however, irrespective of whether they have a sexual relationship or not, maintains their sexuality.

To understand the sexuality of the elderly, it is necessary to consider how factors such as culture, religion and education influence the sexual behavior of elderly persons and determine how sexuality will be experienced during this stage of life. ${ }^{6}$ Sexuality in aging should not be viewed as incompatible, as it is present in all stages of human development, even though sexual activity may decrease or be absent among the elderly. ${ }^{11}$

The exercise of sexuality during the aging process needs to be understood as a positive experience from the viewpoint of both health professionals and the elderly, provided he or she desires it. Whether through campaigns, educational activities or routine medical appointments, the issue needs to be incorporated and present in the health care of the elderly. ${ }^{12}$ 
In general, the elderly persons investigated in this study felt dissatisfied with their body image in relation to overweight, especially females. The body image variable was significant in the binary correlation of the study, and body satisfaction was related to the has sex. Dissatisfaction could be related to changes associated with aging, with waist circumference the measurement most frequently related to this negative perception. ${ }^{13}$

Although sexual practice is part of the expression of sexuality, the conception of the elderly is still rooted in genitality, even though it is not the only form. Only $20.4 \%$ reported that sexuality involves more than sex, being linked with well-being, affection, companionship and the relationship of the individual with themselves and others.

The sense that sexuality represents the sexual act remains common among the elderly, as well as the denial of other forms of sexuality, such as eroticism, affection and prazer. ${ }^{14}$ Therefore, knowledge about the fullness of the sexual experience is necessary for health professionals involved in the sexual education of the elderly, through strategies that allow dialogue and discussion on the topic.

Using the sexual quotient questionnaire female version with 38 elderly women, Polizer and Alves ${ }^{15}$ observed that interest in sex and sexual desire continue in this age range, with $29 \%$ and $34.2 \%$ of those interviewed describing their sexual satisfaction as good to excellent and fair to good, respectively. In the present study, although $67.7 \%$ of respondents did not engage in sexual activity, thinking about sex was present in 51.5\% of those interviewed, showing that even in the aging phase the presence or absence of a partner does not prevent the occurrence of sexual desire.

In this study, although $67.7 \%$ of respondents did not have sex, thinking about sex was present in $51.5 \%$, showing that even in the aging phase the presence or absence of a partner does not prevent the occurrence of sexual desire.
Recognizing that sex continues in old age means considering that elderly persons are also exposed to diseases related to unprotected sex. In a study by Bezerra et al. ${ }^{16}$, however, the elderly persons themselves did not recognize this scenario of vulnerability, indicating the need for public policies that meet this demand among older persons, as well as treating chronic diseases such as hypertension and diabetes.

Often the regularity of sexual intercourse is related to the presence of a fixed partner ${ }^{17}$, corroborating the study of Ferreira et al. ${ }^{18}$ where the investigated elderly persons said that sex with a partner was an obligation, or was only performed to satisfy the other, or for no reason at all. The disappointments and resentments experienced in the life of a couple have also been described as factors that interfere with sexual practice, and were found in greater numbers among women. ${ }^{8}$

Lindau et al. ${ }^{19}$ reported that the prevalence of sexual activity declines with age, and that women are less likely to have intercourse than men at all ages, with those who continued sexual practice indicating at least one problem that interfered with sex. The women described vaginal dryness and decreased sexual desire, while men mentioned difficulty with erections as factors that interfered with sexual activity. The elderly persons described an interest in continuing sex, which they considered an aspect of satisfaction with life ${ }^{20}$, meaning that health professionals should include issues involving sexuality in their clinical activities with the elderly.

No scientific evidence was found that discussed the relationship between physical exercise and the reduction of thinking about sex or sexual activity. Although in the final analysis the holistic conception of sexuality was significant among elderly persons who had nine years or more of study and those who practiced physical exercise, exhibiting a lower probability of thinking about sex and sexual activity, the bivariate correlations should be noted, as they infer that other factors may influence the experience of sexuality of elderly persons. 


\section{CONCLUSION}

Studies on sexuality in old age are of paramount importance in the field of Gerontology and Geriatrics, allowing new spaces to be opened in the clinical practice of health professionals to discuss the health of the elderly, considering that sexuality is part of the promotion of the well-being and quality of life of the elderly.

Further studies that address the issue of sexuality in old age should be considered, with a view to promoting the health of older people in a more holistic and less biologistic sense, where individuals should be viewed in their entirety and not be reduced to chronic diseases, to which people are more vulnerable in their advancing years.

It can be concluded from the present study that a range of factors interfere with the exercise of sexuality among the elderly, including social, cultural and physiological issues. These should be considered in the promotion of the sexual education of older persons within a health education strategy.

\section{REFERENCES}

1. Marques ADB, Silva RP, Sousa SS, Santana RS, Deus SRM, Amorim RF. A vivência da sexualidade de idosos em um centro de convivência. Rev Enferm Cent. -Oeste Min 2015;5(3):1768-83.

2. Trindade WR, Ferreira MA. Sexualidade feminina: questões do cotidiano das mulheres. Texto \& contexto Enferm 2008;17(3):417-26.

3. Coelho DNP, Dailer DV, Santana RF, Santo FHE. Percepção de mulheres idosas sobre sexualidade: implicações de gênero e no cuidado de enfermagem. Rev RENE 2010;11(4):163-73.

4. Bastos CC, Closs VE, Pereira AMVB, Batista C, Idalêncio FA, Carli GA, et al. Importância atribuída ao sexo por idosos do município de Porto Alegre e associação com a autopercepção de saúde e o sentimento de felicidade. Rev Bras Geriatr Gerontol 2012;15(1):87-95.

5. Netto MP. O estudo da velhice: histórico, definição do campo e termos básicos. In: Freitas EV, Py L, editores. Tratado de geriatria e gerontologia. $3^{\mathrm{a}}$ ed. Rio de Janeiro: Guanabara Koogan; 2011. p. 2-12.

6. Grandim CVC, Sousa AMM, Lobo JM. A prática sexual e o envelhecimento. Cogitare Enferm 2007;12(2):204-13.

7. Vasconcellos D, Novo RF, Castro OP, Vion-Dury K, Ruschel A, Giami PCA. A sexualidade no processo do envelhecimento novas perspectivas comparação transcultural. Estud Psicol (Campinas) 2004;9(3):413-19.
8. Vieira KFL, Coutinho MPL, Saraiva ERA. A sexualidade na velhice: representações sociais de idosos frequentadores de um grupo de convivência. Psicol Ciênc Prof 2016;36(1):196-209.

9. Linhares FMP, Pottes AF, Araújo EC, Menezes EP, Siqueira KA. Percepção de idosos sobre o exercício da sexualidade atendidos no Núcleo de Atenção ao Idoso em Recife, Brasil. Rev Enferm Herediana 2008;1(2):93-103.

10. Chaim J, Izzo H, Sera CTN. Cuidar em saúde: satisfação com imagem corporal e autoestima de idosos. Mundo Saúde 2009;33(2):175-81.

11. Almeida T, Lourenço ML. Envelhecimento, amor e sexualidade: utopia ou realidade. Rev Bras Geriatr Gerontol 2007;10(1):101-13.

12. Silva MM, Vasconcelos ALR, Ribeiro LKNP. Caracterização epidemiológica dos casos de AIDS em pessoas com 60 anos ou mais, Pernambuco, Brasil, 1998 a 2008. Cad Saúde Pública 2013;29(10):2131-35.

13. Pereira EF, Teixeira CS, Borgatto AF, Daronco LSE. Relação entre diferentes indicadores antropométricos e a percepção da imagem corporal em idosas ativas. Rev Psiquiatr Clín (São Paulo) 2009;36(2):54-9.

14. Oliveira AMM, Lopes MEL, Evangelista CB, Oliveira AEC, Gouvéia EML, Duarte MCS.

Representações sociais e envelhecimento: uma revisão integrativa de literatura. Rev Bras Ciênc Saúde 2012;13(3):427-34. 
15. Polizer AA, Alves TMB. Perfil da satisfação e função sexual de mulheres idosas. Fisioter Mov 2009;22(2):151-8.

16. Bezerra VP, Serra MAP, Cabral IPP, Moreira MASP, Almeida SA, Patrício ACFA. Práticas preventivas de idosos e a vulnerabilidade ao HIV. Rev Gaúch Enferm 2015;36(4):70-6.

17. Fernandes MGM, Garcia LG. O corpo envelhecido: percepção e vivência de mulheres idosas. Interface Comun Saúde Educ 2010;14(35):879-90.
18. Ferreira KS, Silva MG, Cherem TMDA, Araújo CLO. Percepção dos idosos perante o sexo na idade avançada. Geriatr Gerontol 2009;3(4):182-88.

19. Lindau ST, Schumm LP, Laumann EO, Levinson W, O’Muircheartaigh CA, Waite LJ. A study of sexuality and health among older adults in the United States. N Engl J Med 2007;357(8):762-74.

20. Woloski-Wruble AC, Oliel Y, Leefsma M, HochnerCelnikier D. Sexual activities, sexual and life satisfaction, and successful aging in women. J Sex Med 2010;7(7):2401-10

Received: February 23, 2016

Reviewed: September 06, 2016

Accepted: September 21, 2016 